\title{
Need for a balance between short food supply chains and integrated food processing sectors: COVID-19 takeaways from India
}

\author{
Venkatesh Thulasiraman $^{1,2}$ (1) M. S. Giri Nandagopal ${ }^{3}$ - Anjineyulu Kothakota ${ }^{1,2}$
}

Revised: 19 September 2020/ Accepted: 21 December 2020/Published online: 6 January 2021

(C) Association of Food Scientists \& Technologists (India) 2021

\begin{abstract}
India is an agrarian country with a long history of traditional food processing practices and Short food supply chains (SFSC). However, last few decades saw a huge investment and steady increase in large scale integrated food processing units to combat globalization, food security and India's export demands. Recent outbreak of COVID-19 has manifested the drawbacks in the existing production and supply chain system with a wide range of issues and enforces the need for a more balanced approach. This scenario can be commonly observed in many other agrarian developing nations. This article discusses various issues concerning the existing integrated food processing sectors such as high energy consumption, greenhouse gas emissions and food insecurity during disasters and pandemic outbreaks. Moreover, we emphasise a more sustainable approach with a better balance and understanding between SFSC and integrated food processing. A potential solution in this scenario would be, rejuvenating SFSC and traditional food processing approaches along with integrated food processing units. An approach of this kind, opens up new possibilities for a next generation processsupply system.
\end{abstract}

Venkatesh Thulasiraman and M. S. Giri Nandagopal have contributed equally to these work.

Venkatesh Thulasiraman

venkateshsowdhill@gmail.com; venkatesh@niist.res.in

1 Agro Processing and Technology Division, CSIR - National Institute for Interdisciplinary Science and Technology, Thiruvananthapuram 695 019, India

2 Academy of Scientific and Innovative Research (AcSIR), Ghaziabad 201 001, India

3 Department of Mechanical Engineering, Indian Institute of Technology Kharagpur, West Bengal 721 302, India
Keywords COVID-19 - Processed foods - Energy demand - Short food supply chains - Traditional food sectors · Food supply

\section{Introduction}

Owing to recent outbreak of COVID-19 pandemic, Indian economy has been hit seriously and poses serious thread to human's lives, health and country's economic condition. With progress of disease spread, there has been serious lockdown imposed across the country which has made it difficult for farmers and Agro producers for effective postharvest management and to bring the products to the market. The Food and Agriculture Organization (USA 2020) states that COVID-19 has been affecting the agriculture to the great extend in supply and demand for agro produces and food. Also, supply chain disruptions to food supply owing to labour shortages, transportation of produced products, shut-down of food processing units and inter-border transportation issues caused a major blow to the exciting food supply system.

Since the onset of the Covid-19 pandemic, food shelves were found empty mainly in urban areas where the shipping of food has become tremendously difficult due to the unprecedented lockdown. However, to ensure food security authorities has approached food enterprises to gather information about the supplies of basic food commodities and connected them with seller, which was a tedious process in a country like India with very high population. In a long run, Apps using Big Data and artificial Intelligence will be a great option to collect real-time data in order to improve the communication between farmers and suppliers with markets and get acute responses if any alterations of demand occur (Galanakis 2020). However, developing and 
implementation of such system requires several brainstorming and appropriate education to the farmers and small-scale supplier, who are not much exposed in handling such technologies. Hence a better option will be of establishing "local food supply chains" for self-reliability and sustainability (Rizou et al. 2020). With government's recent initiatives like "Vocal for Local with Global outreach", "Agri Infrastructure Fund" and "Formalization of MSME's" have led to re-consider our approach towards a better balance between local food supply chains and integrated food processing units.

This article begins with introduction of green revolution in India and its necessity for combating poverty and eliminating hunger in post-independent India. Green revolution and subsequent agriculture revolution in India have led to introduction of agri machineries, food processing units and rapid industrialization of agriculture. However, it led to the growth of greenhouse emissions, loss of job for marginal agri labours and excessive energy consumption in food industries. The paper then examines the impact of COVID-19 with case studies of dairy processing and sugar production and concludes the need of an integrated inclusive food policy for food processing.

\section{Green revolution and food security}

Green revolution, popularly known as Third Agricultural Revolution was introduced globally in late 1960s with the intention of improving the crop yield and agricultural production world-wide. Green revolution introduced the use of chemical fertilizers, agro chemicals and machineries for bulk production of agro products (Phillips 2014). In order to combat with India's growing population and to have a balance between developing industrialization and the need of providing food security to Indian population, green revolution was inevitable to India (Hardin 2008). With the introduction of genetically modified seeds, high yielding crop varieties, pesticides/fertilizers, improved rural infrastructure, land reforms, and use of advanced machineries led India to produce surplus wheat and rice that would cater the food security of large population of the country (Scroll and For 2012).

As a continuity of technological interventions in food processing sectors, there is also a growing interest among global scientists towards recovery of high value compounds from food wastes being generated. For example, agro produces rich in carbohydrates such as rice, wheat and oats by-products can be effectively used for recovery of high value compounds such as albumin, globulin, insoluble dietary fibres and hemi-cellulose. Similarly, fruits and vegetables peels such as Apple pomace, lemon peels, grape extracts etc., can be used for the extraction of pectin's, phenolic compounds and carotenoid compounds. Value added compounds can be extracted using suitable extraction techniques followed by isolation and purification steps. (Galanakis 2012).

Emerging technologies like membrane based filtration and separation techniques for effective separation of high value compounds like dietary fibers, polyphenols and flavonoids (Galanakis 2015) and non-thermal techniques like ultra-sound and micro-wave assisted extraction of high value compounds, pulsed electric field and applications of nano-technology have emerged as a promising tool for effective agricultural by-products/waste utilization (Galanakis 2013).

Nevertheless, Green revolution has its own criticisms. Lack of enough income generation to marginal farmers, dependence of third party for pesticides and fertilizers, loss of indigenous crop varieties, increased demand of electricity and non-availability of seeds are few issues associated with green revolution (Bowonder 1979). During the onset of green revolution, Indian agriculture accounted for around $80 \%$ of the total employment and $50 \%$ of the gross domestic product. However, currently, employment in agricultural sector steeps down to 50\% in India. Interesting, about $50 \%$ of the cultivable lands in India are with the small-scale farmers who owned a farm size of less than 2 acres. Despite the population associated with agriculture has declined over the years, with the help of High Yield Variety Technology (HYVT) which is introduced during Green Revolution, the food grain production in India had been increased from 50 million tons in the year 1950 to 95 million tons in the year 1968 (Dhanagare 1988). With surplus agriculture production and less dependence of manpower and technological interventions, there is a rapid shift from agri-culture to agri-business in India. NITI Aayog 2018 report states that post-harvest losses in India is around Rs 90,000 crore INR and in-order to reduce the food wastes and better price realization, integrated food processing and post-harvest interventions have become necessary (NITI Aayog 2018).

\section{Food processing sectors and green house gas emissions}

India is steadily increasing its interest in the area of processed foods and Ready to Eat/Ready to Serve food products (Convenient food products). Recent studies in food patterns of Indians shows that per capita consumption of processed fruits, vegetables and dairy (cheese, butter and ghee) is steadily increasing, whereas the per capita consumption of stable food like wheat and rice remains constant (Alae-Carew et al. 2019). It is worthy to note here that India's agriculture sector accounted for around 18\% of 
India's green-house gas (GHG) emissions in the year 2007 and nevertheless to say that, due to growing need for processed food, contribution of GHG emissions due to agriculture sector have been projected to increase by around 25\% in the year 2030 (Nicot and Duncan 2012). The reason attributed to increase in GHG emissions due to agriculture sector in India is excessive use of fertilizers, use of electricity for irrigation and water supply and food processing industries (Garg et al. 2001). Statistics shows that almost $70 \%$ of total nitrous oxide emissions in the year 2010 from agriculture sector is due to the use of fertilizers. Table 1 shows the various sources for nitrous oxide emissions in the year 2010 (Nicot and Duncan 2012).

With green revolution and use of excessive fertilizers add to GHG emissions, another concerning factor is increase in use of processed foods among general public of Indian population. It has been observed recently that there is a huge increase in intake of sugar, oils and processed foods among urban population of India (Meenakshi 2016). However, processed foods are convenient to cook in shorter duration, processed foods are gaining momentum among urban and working population. However, due to high sugar content and presence of preservatives, processed foods have its own negative implications like increase in overall intake of sugars, saturated trans-fat and salt (Thow et al. 2016).

Processed foods demands sophisticated facilities like primary cleaning units (Faille et al. 2018), separation units (Compton et al. 2018), size reduction equipment, packaging units (Rodríguez-Rojas et al. 2019), processing lines and techniques like drying (Sagar 2010), size reduction operations (Meng et al. 2018) physical preservation techniques like ozonation (Pandiselvam et al. 2017), UV radiation (Kuan et al. 2013), Plasma techniques (Thirumdas et al. 2018) etc. Hence, for an efficient food processing unit there is a need of a large and dedicated workspace, well planned industrial set-up with adequate electrical and water supply, safe and healthy operating conditions etc.

For better connectivity and reach, innovations in food sectors like Disruptive technologies are indeed necessary post COVID-19. Disruptive technology, in general, refers to an innovation that creates a new market and value network which will eventually cause a disturbance to an existing market, thereby replacing the well-established technologies and product (Christensen et al. 2018). Post
COVID-19, the concept of disruptive innovation may also be applied to food industry towards the introduction of indigenous technologies, local food supply chains, increase in consumption of nutraceuticals and functional foods and development of fortified food products. Nevertheless, post COVID-19 disruptive innovation may lead to localized opportunities, utilization of indigenous products, arrival of new venture capitals and start-ups and innovative technologies may bloom the food market (Rowan and Galanakis 2020).

\section{Energy demand in food sectors}

Energy estimation of various food products show that instant coffee powders, dairy industries, chips and bread making are the most energy consuming industry. Thermal processing involved with various food products consume more energy. Also, transportation of food from one place to another have been increased in recent days due to integrated large scale food processing units (Ladha-Sabur et al. 2019).

Globalization of the food sector leads to integrated food processing units, which in-turn poses environmental threats like higher energy consumption, usage of plastics for food wrapping and cost of transportation (Coley et al. 2009). For example, Table 2 (Adapted from (Ladha-Sabur et al. 2019)) shows the energy and fuel requirement of various food products, prevalent to large scale food processing industries.

With reference to Table 2, it is evident that sugar, breakfast cereals and milk powder consumes higher amount of energy per $\mathrm{kg}$ of final product. This is due to the fact that both drying (heat requirement) and milling (size reduction) consumes high amount of energy compared to other unit operations. Though, renewable energy initiatives like solar energy have been proven to be a successful alternative for dehydration operations (Eswara and Ramakrishnarao 2013), extension of renewable energy options for entire food processing still remains a challenge, which results in high energy demand for food processing sectors.
Table 1 Contribution of various sources for total nitrous oxide emission in agriculture sector of India in the year 2010

\begin{tabular}{ll}
\hline Source & $\%$ contribution to nitrous oxide emission \\
\hline Fertilizers & 77 \\
Animal and green manure & 13 \\
Soil mineralization & 9 \\
Crop residue & 1 \\
\hline
\end{tabular}


Table 2 Energy requirement for various processed food products

\begin{tabular}{lll}
\hline Food product & Major unit operation/process & Energy and fuel demand per kg of final product \\
\hline Sugar & Crushing, evaporation and crystallization & 25.0 \\
Breakfast cereals like oats, corn flakes etc., & Grinding, milling, drying and baking & 18.0 \\
Milk powder and dairy processing & Sterilization, evaporation and spray drying & 16.22 \\
Frozen meat products & Deboning, free drying and size reduction & 5.0 \\
Concentrated milk & Pasteurization and packaging & 4.6 \\
Processed (dried) fruits and vegetables & Size reduction and drying & 4.27 \\
\hline
\end{tabular}

\section{Effect of covid-19 on food supply}

COVID 19 a coronavirus pandemic caused by severe acute respiratory syndrome coronavirus 2 (SARS-CoV-2). The World Health Organization declared the outbreak as a Public Health Emergency of International Concern and pandemic. As a result of COVID-19, serious lock-down was implemented across the nation and borders between various states were sealed. During such crisis, operating of food processing units becomes questionable and availability of processed foods during lock-down period becomes difficult. The potential solution for such situation will be a more restructured and rejuvenated shortly distributed food supply chains system. Moreover, SFSC generates micro-economy, more local employment and prevents the excess migration of rural population to urban, leading to rapid and uncontrolled urbanization.

COVID-19 and subsequent restrictions in travel has put huge burden in both supply and demand of food products. The prevalent condition may lead to attempts such as consumers growing their own food crops, impact on global food trade such as restriction on imports of food products and encouragement of local food production (Henry 2020; Blay-Palmer et al. 2020).

Integrated food processing concept was found to be more efficient and suitable for highly industrialised countries where the population involved with agriculture is very less. For example, as per the Census of Agriculture, USA 2017, it is revealed that around 34 lakhs of people in USA are involved in agriculture employment which is a mere $1 \%$ of the entire population of USA (NASS 2017). For such countries with less agricultural population, industrialization and integrated food processing may be apt and necessary. However, during the pandemic, countries like Italy, Spain and USA who rely on integrated food processing concept too suffered largely and their food supply system was very badly affected (Cappelli and Cini 2020; Hobbs 2020).

Now, considering the case of more agrarian country like India where around $50 \%$ of the India's total workforce depends on agriculture and hence localized food chain, localized food processing and allied sectors plays a huge role in terms of employment, sustainability and availability (GOI 2019b). In the year 1996, the European Commission directed that local food supply can significantly reduce the transport cost and delivery time of processed foods in times of emergency (Clark 2018). Moreover, India's 68\% of the population resides in rural India, which directly or indirectly depends on agriculture and also villages are evenly distributed in India with almost all states having more than $50 \%$ of rural population (GOI 2019b). One alarming fact from census of India 2011 is the decline of rural population from $89 \%$ in 1901 to $68 \%$ in the year 2011, which shows the constant migration of rural population to urban cities due to lack of employment leading to overcrowded cities and decline in agriculture (Census 2011). With borders locked down and restrictions of movement across nation is implemented due to COVID-19, the solution for uninterrupted food supply lies in local productions and traditional food sectors, which is less dependent on sophisticated large-scale processing units and bulk transportation. Hence, reviving local food supply and traditional food sectors will play a huge role in prevention of rural migration as well as efficient distribution and availability of food during the high-risk situations. For a better demonstration of the scenario, let us discuss and compare the case of dairy milk outlets with raw milk supply and Jaggery and Sugar production in terms of energy demand and availability.

\section{Case 1: dairy industries vs local milk supply}

Production of Milk powder requires huge energy for the spray drying process, which is about 10-20 times higher than the conventional drying process through evaporation (Ramírez et al. 2006). Moreover, to increase its shelf life up to 60-120 days, techniques like ultra-high sterilization (Chavan et al. 2011) is used which in turn needs excess amount of energy. Most of the dairy industries require energy for pumps, refrigeration and thermal energy as 
steam for evaporation and pasteurization processes ( $\mathrm{Xu}$ and Flapper 2011).

Operating a dairy industry requires skilled man-power, continuous transportation facilities, raw materials, consumables, packaging materials and uninterrupted electricity and unavailability of any of this may lead to a havoc in the smooth functioning of dairy industries. With lock-down being implemented across India due to COVID 19 pandemic, dairy industries face difficulty in supply of milk packets across states, leading to dip in dairy production. The case is prevalent across nation due to lack of transportation facilities and raw materials during lock-down period.

On the other hand, if we consider SFSC which happens directly between producers (farmers) and consumers, the issues concerning transportation, processing and excess energy requirement can be avoided. Statistics from Ministry of Fisheries, Animal Husbandry and Dairying, India, states that around $48 \%$ of the milk is consumed at the producer level without processing, whereas the rest $52 \%$ of the milk is processed in dairy industries (Ministry of Fisheries 2020). India's milk demand till date is predominantly met by the local farm supply and informal sectors. However, with governments initiative towards making dairy cooperative societies, dairy processing units etc., modern milk value chains are gaining popularity and momentum among urban population steadily(Kumar et al. 2018).

India's dairy sectors contribution to agriculture stands at $19 \%$ and India is the world's largest producer of milk. Unlike other agriculture and food processing sectors, India's dairy business is dominated by small scale farmers who are involved with local milk supply. Whatsoever, the spread of dairy industries in India is not even and hence the globalization effects of dairy industry is debatable in terms of rural employment, micro-economics and availability issues (Kumar et al. 2019). It is absolute necessary to ensure that industrialization of dairy industries should not eliminate the local milk supply and its economics, so that uninterrupted milk supply can be realizable always even during pandemic period.

\section{Case 2: revival of traditional food sectors-case study of jaggery}

Sugar Industries also face tough times during the time of COVID-19 lock-down due to issues in transportation of sugar-cane to the sugar mills, availability of chemicals for processing etc., Reports from Indian Sugar Mill Association states that there is a considerable decline in the sugar production due to non-availability of important materials like lime, sulphur, bags, trucks for transportation etc. As per news reports, it has been reported that almost $70 \%$ of the sugar mills in Maharashtra have been closed due to COVID-19 pandemic (Solomon et al. 2020).

While, Jaggery, a natural sweetener, which is made from the direct evaporation of cane juices followed by subsequent drying, have been traditionally used in India as a natural sweetener. Almost $70 \%$ of worlds jaggery demand is met by India and India is the leading producer of Jaggery in the world (Kumar and Kumar 2018). Traditionally, jaggery have been manufactured in India and is one of the important decentralized agricultural sectors in India. These plants are operated by simple open pan evaporation process by local artisans (Anwar 2010). Moreover, numerous reports suggest jaggery over refined sugar due to their high nutritional value. A comparison showing the contents of sugarcane juice, refined sugar and jaggery is shown in Table 3. It is evident that, jaggery retains almost all the nutrients and minerals present in sugarcane juice. (Kumar and Singh 2020).

Since Jaggery is produced at the place of harvest in a decentralized way, the dependence of electricity, transportation and packaging is less for jaggery production when compared to refined sugar. In terms of energy consumption, energy demand for the production of $1 \mathrm{~kg}$ of jaggery stands is $16 \mathrm{MJ} / \mathrm{kg}$ (Pattnayak and Misra 2004) against $25 \mathrm{MJ} / \mathrm{kg}$ for sugar.

Ministry of Micro, Small and Mini Enterprises of India reports around 1,00,000 jaggery production units operating across India, mainly spread in the Indian states of Uttar Pradesh, Maharashtra, Tamil Nadu and Madhya Pradesh (MSME 2018). However, jaggery consumption and production have been declining since 1960s and the production of jaggery fell from 60 metric tonnes in the year 1950 to 30 metric tonnes in the year 2010 (Fig. 1), with production of jaggery is declining at the rate of $1.3 \%$ per year, whereas sugar production is increasing at the rate of $3.7 \%$ per year (Bhardwaj 2013) (Nath et al. 2015). Despite Jaggery production, being indigenous traditional knowledge, easy to process and highly nutritious, consumption and production have been in decline due to inefficient heating process, addition of chemicals for solidification, unhygienic environmental processing conditions etc.,(Sardeshpande et al. 2010). Hence, more research needs to be carried out for the revival of traditional sectors like Jaggery production. Moreover, the energy dependence of jaggery production can further be reduced by incorporating suitable renewable energy options. For example, utilization of solar collectors can be employed to enhance the concentration of sugar-cane juice, thereby considerable amount of energy is reduced. Solar preheating of sugarcane juice to near boiling temperature prior to evaporation process is found to save around $2360.44 \mathrm{~kJ}$ of heat energy 
Table 3 Nutritional comparison of refined sugar and jaggery (Kumar and Singh 2020; Gangwar et al. 2015)

\begin{tabular}{llll}
\hline Content & Sugarcane juice & Refined sugar & Jaggery \\
\hline Sucrose $\%$ & $10-15 \%$ & $99.5 \%$ & $80-85 \%$ \\
Moisture $\%$ & $85-90 \%$ & $0.2-0.4 \%$ & $10-15 \%$ \\
Iron $(\mathrm{mg} / 100 \mathrm{~g})$ & 15 & - & $10-15$ \\
Sodium $(\mathrm{mg} / 100 \mathrm{~g})$ & 44 & $<5$ & $25-30$ \\
Calcium $(\mathrm{mg} / 100 \mathrm{~g})$ & 13 & $<5$ & $40-50^{*}$ \\
Phosphorous $(\mathrm{mg} / 100 \mathrm{~g})$ & 10 & $<5$ & $40-50^{*}$ \\
Potassium $(\mathrm{mg} / 100 \mathrm{~g})$ & 12 & - & $7-12$ \\
Vitamin B $(\mathrm{mg} / 100 \mathrm{~g})$ & 33 & $20-25$ \\
\hline
\end{tabular}

*increase in value is due to the treatment of solidification and clarification purposes

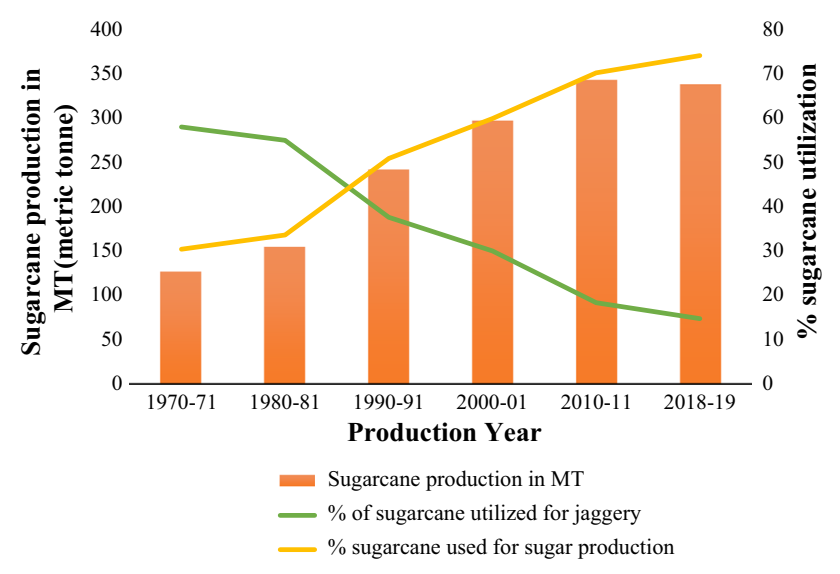

Fig. 1 Sugarcane production and consumption in India (1970-2019). (Gangwar et al. 2015)

and $0.23604 \mathrm{~kg}$ of dry bagasse could be saved per $\mathrm{kg}$ of jaggery preparation (Jakkamputi et al. 2016).

Thus, boosting up the localized traditional sectors will be very helpful in food security during pandemics too.

\section{Need of an effective balance in food production}

The policies and regulations related to food supply and agriculture should be framed in accordance with the country's economy and agrarian culture. Food and Agriculture Organization of the United Nations (FAO) stressed the importance of local food production and micro economy for effective poverty-hunger reduction. FAO in its '2030-Agenda for Sustainable Development' released 17 Sustainable Development Goals (SDGs) that can be implemented by countries according to their policies and regulations. SDGs stressed the importance of family farming, local cultivation and short supply chains as an effective way to combat poverty across the globe (McKenzie and Williams 2015).

In India, policies such as Public Distribution Systems (PDS) have been existing well before its Independence has proven as a best integrative approach for local crop production and bulk distribution through the involvement of Government (Qureshi et al. 2015). Also, linking of agriculture with other sectors, predominantly energy, for renewable energy generation like bio-gas will also provide a sustainable environment and a scope for inclusive growth (Grote 2014). Moreover, production of healthy snacks and ready to eat food items in a distributive manner, say, street side shops and small hotels, is proven to be a successful model for promoting rural-urban self-employment and food security (Patel et al. 2014). Another aspect towards technological interventions include introduction of less capital invested equipment in small scale like hand operated or pedal operated de-husking and de-milling equipment for crop processing etc. (Miller-Tait et al. 2019).

Thus, for an effective food security, the following sectors have to be boosted and promoted.

(1) Public Distribution System.

(2) Promotion of entrepreneurship through local help groups and associations towards healthy snack and food items and.

(3) Development of equipment for small scale crop processing proves to be an excellent solution for improving rural economy and employment without causing havoc to food security and environmental issues.

Next, utilization of agricultural technologies should be used towards minimizing the post-harvest losses during surplus production. Another interesting fact is that there was an equal distribution of agricultural commodities and food products among global population in the year 1990, but, due to introduction of high-tech agricultural technologies, developed countries started producing surplus food and thus increasing their export potentials due to globalization efforts, whereas developing and underdeveloped countries couldn't able to produce the desired agricultural inputs due to diminishing agriculture and increasing industrialization. This has led to the widening of unequal distribution of food supply (Wu et al. 2014). 
Expansion of industrial agriculture in India does not guarantee a better life for marginalized farmers, especially rural population. However, the target of zero hunger and providing food for entire global population would never be achieved without integrating sophistication and modernization in food processing. Hence, a clean understanding and balance between integrated food processing sectors and local supply is needed in India, with significant importance being given to Local food supply considering the agrarian population of India.

\section{Conclusion}

There is an emerging trend of processed fast foods, which may provide a convenient purchase and easy cooking options, but India's backbone lies in farming and localized food supply. There are plenty of government initiatives towards boosting investments in food processing sectors via permitting Foreign Direct Investments, large-scale processing units, modernization of agriculture, machineries development etc. However significant importance and consideration should be given to SFSC with a focussed research towards local food chain sectors, development and revival of traditional food sectors, technological interventions of traditional knowledge etc. Informal food sectors like raw milk trading, jaggery production, cultivation and preservation of indigenous fruits, vegetables and crop varieties offer excellent employment opportunities and considerable food availability when operated at small scale. Hence, the future direction should be of a balanced model between SFSC and integrated food processing industry.

Acknowledgement Venkatesh Thulasiraman would like to express his sincere gratitude and thanks to his Research Supervisor Dr. Anjineyulu Kothakota, Scientist and his senior colleagues Dr. Reshma, Principal Scientist and Mr. Venugopal V V, Senior Principal Scientist for their constant motivation and support throughout his scientific career.

Funding Venkatesh Thulasiraman thank Department of Science and Technology, Govt. of India for the funding [Sanction No: DST/TDT/ AGRO-46/2019]. Dr. M. S. Giri Nandagopal thank Science and Engineering Research Board (SERB), Department of Science and Technology, Govt. of India for National Post-Doctoral Fellowship [Sanction No: -PDF/2018/001486].

\section{Compliance with ethical standards}

Conflict of interest There is no conflict of interest while publishing this article.

\section{References}

Alae-Carew C, Bird FA, Choudhury S et al (2019) Future diets in India: a systematic review of food consumption projection studies. Glob Food Sec 23:182-190. https://doi.org/10.1016/j. gfs.2019.05.006

Anwar SI (2010) Fuel and energy saving in open pan furnace used in jaggery making through modified juice boiling/concentrating pans. Energy Convers Manag 51:360-364. https://doi.org/10. 1016/j.enconman.2009.09.033

Bhardwaj A (2013) The Gur and Khandsari Industry and its practical impact on Indian sugar consumption level. Indian Sugar Mills Association, https://www.indiansugar.com/uploads/WABCG25th_March_2013-_Amit_Bhardwaj-_ISMA.pdf. Accessed $1 \overline{9}$ Sept 2020

Blay-Palmer A, Carey R, Valette E, Sanderson MR (2020) Post COVID 19 and food pathways to sustainable transformation. Agric Hum Values 37:517-519. https://doi.org/10.1007/s10460020-10051-7

Bowonder B (1979) Impact analysis of the green revolution in India. Technol Forecast Soc Chang 15:297-313. https://doi.org/10. 1016/0040-1625(79)90023-4

Cappelli A, Cini E (2020) Will the COVID-19 pandemic make us reconsider the relevance of short food supply chains and local productions? Trends Food SciTechnol 99:566-567. https://doi. org/10.1016/j.tifs.2020.03.041

Census of India (2011) Rural urban distribution of population (provisional population totals) Government of India. http:// censusindia.gov.in/2011-prov-results/paper2/data_files/india/ Rural_Urban_2011.pdf. Accessed 19 Sept 2020

Chavan RS, Chavan SR, Khedkar CD, Jana AH (2011) UHT milk processing and effect of plasmin activity on shelf life: A review. Compr Rev Food Sci Food Saf 10:251-268. https://doi.org/10. 1111/j.1541-4337.2011.00157.x

Christensen CM, McDonald R, Altman EJ, Palmer JE (2018) Disruptive innovation: an intellectual history and directions for future research. J Manag Stud 55:1043-1078

Clark LF (2018) Policy conflicts in global food assistance strategies: balancing local procurement and harmonization. Food Secur 10:211-222. https://doi.org/10.1007/s12571-017-0758-z

Coley D, Howard M, Winter M (2009) Local food, food miles and carbon emissions: a comparison of farm shop and mass distribution approaches. Food Policy 34:150-155. https://doi. org/10.1016/j.foodpol.2008.11.001

Compton M, Willis S, Rezaie B, Humes K (2018) Food processing industry energy and water consumption in the Pacific northwest. Innov Food SciEmergTechnol 47:371-383. https://doi.org/10. 1016/j.ifset.2018.04.001

Dhanagare DN (1988) The green revolution and social inequalities in rural India. Crit Asian Stud 20:2-13. https://doi.org/10.1080/ 14672715.1988.10404444

Eswara AR, Ramakrishnarao M (2013) Solar energy in food processing - a critical appraisal. J Food SciTechnol 50:209-227. https://doi.org/10.1007/s13197-012-0739-3

Faille C, Cunault C, Dubois T, Bénézech T (2018) Hygienic design of food processing lines to mitigate the risk of bacterial food contamination with respect to environmental concerns. Innov Food SciEmergTechnol 46:65-73. https://doi.org/10.1016/j.ifset. 2017.10.002

Galanakis CM (2020) The food systems in the era of the coronavirus (CoVID-19) pandemic crisis. Foods 9:1-10. https://doi.org/10. 3390/foods 9040523

Galanakis CM (2012) Recovery of high added-value components from food wastes: conventional, emerging technologies and 
commercialized applications. Trends Food SciTechnol 26:68-87. https://doi.org/10.1016/j.tifs.2012.03.003

Galanakis CM (2015) Separation of functional macromolecules and micromolecules: from ultrafiltration to the border of nanofiltration. Trends Food SciTechnol 42:44-63. https://doi.org/10.1016/ j.tifs.2014.11.005

Galanakis CM (2013) Emerging technologies for the production of nutraceuticals from agricultural by-products: a viewpoint of opportunities and challenges. Food Bioprod Process 91:575-579. https://doi.org/10.1016/j.fbp.2013.01.004

Gangwar LS, Solomon S, Anwar SI (2015) Policy brief technological and policy options for modernization of jaggery Industry in India, Indian Institute of Sugarcane Research. http://www.iisr. nic.in/download/publications/PolicyPaper_Gangwar.pdf. Accessed 19 Sept 2020

Garg A, Bhattacharya S, Shukla PR, Dadhwal VK (2001) Regional and sectoral assessment of greenhouse gas emissions in India. Atmos Environ 35:2679-2695. https://doi.org/10.1016/S13522310(00)00414-3

GOI (2019b) Ministry of Agriculture and Farmers Welfare, Annual Report 2018-2019. Department of Agriculture, Cooperation and Farmers Welfare, Ministry of Agriculture and Farmers Welfare, Governemnt of India, (2018). http://agricoop.nic.in/sites/default/ files/AR_2018-19_Final_for_Print.pdf. Accessed 19 Sept 2020

Grote U (2014) Can we improve global food security? A socioeconomic and political perspective. Food Secur 6:187-200. https://doi.org/10.1007/s12571-013-0321-5

Hardin LS (2008) Bellagio 1969: the green revolution. Nature 455:470-471. https://doi.org/10.1038/455470a

Henry R (2020) Innovations in agriculture and food supply in response to the COVID-19 pandemic. Mol Plant 13:1095-1097. https://doi.org/10.1016/j.molp.2020.07.011

Hobbs JE (2020) Food supply chains during the COVID-19 pandemic. Can J Agric Econ 68:171-176. https://doi.org/10. $1111 /$ cjag. 12237

Jakkamputi LP et al (2016) Improving the performance of jaggery making unit using solar energy. PerspectSci 8:146-150. https:// doi.org/10.1016/j.pisc.2016.04.019

Kuan YH, Bhat R, Patras A, Karim AA (2013) Radiation processing of food proteins-a review on the recent developments. Trends Food SciTechnol 30:105-120. https://doi.org/10.1016/j.tifs. 2012.12.002

Kumar A, Mishra AK, Saroj S, Joshi PK (2019) Impact of traditional versus modern dairy value chains on food security: evidence from India's dairy sector. Food Policy 83:260-270. https://doi. org/10.1016/j.foodpol.2019.01.010

Kumar A, Saroj S, Joshi PK, Takeshima H (2018) Does cooperative membership improve household welfare? Evidence from a panel data analysis of smallholder dairy farmers in Bihar, India. Food Policy 75:24-36. https://doi.org/10.1016/j.foodpol.2018.01.005

Kumar A, Singh S (2020) The benefit of Indian jaggery over sugar on human health, dietary sugar, salt and fat in human health. Elsevier, Amsterdam

Kumar R, Kumar M (2018) Upgradation of jaggery production and preservation technologies. Renew Sustain Energy Rev 96:167-180. https://doi.org/10.1016/j.rser.2018.07.053

Ladha-Sabur A, Bakalis S, Fryer PJ, Lopez-Quiroga E (2019) Mapping energy consumption in food manufacturing. Trends Food SciTechnol 86:270-280. https://doi.org/10.1016/j.tifs. 2019.02.034

McKenzie FC, Williams J (2015) Sustainable food production: constraints, challenges and choices by 2050 . Food Secur 7:221-233. https://doi.org/10.1007/s12571-015-0441-1

Meenakshi JV (2016) Trends and patterns in the triple burden of malnutrition in India. Agric Econ 47:115-134. https://doi.org/10. 1111/agec.12304 (United Kingdom)
Meng X, Jia F, Xiao Y et al (2018) Effect of operating parameters on milling quality and energy consumption of brown rice. J Food SciTechnol 56:674-682. https://doi.org/10.1007/s13197-0183522-2

Miller-Tait EJ, Mohapatra S, Marty Luckert MK, Swallow BM (2019) Processing technologies for undervalued grains in rural India: on target to help the poor? Food Secur 11:151-166. https://doi.org/ 10.1007/s12571-018-0881-5

Ministry of Fisheries AH and D (2020) An overview of bovine breeding sector in India. In: Department of Animal Husbandry and Dairying. http://www.dahd.nic.in/about-us/divisions/cattleand-dairy-development. Accessed 19 Sept 2020

MSME (2018) A status report on Khandsari Sugar/Jaggery. Minstry of Micro, Small and Medium Enterprises, Government of India. http://msmedikanpur.gov.in/pdf/A\%20Status\%20Report\% 20on $\% 20$ Khandsari $\% 20$ Sugar $\% 20 \& \% 20 J a g g e r y \% 20 \% 20 \mathrm{Gur} \%$ 20Modernisation.pdf. Accessed 26 July 2020

NASS (2017) C farm producers revised census questions provide expanded demographic information, 2017 Census of Agriculture, National Agriculture Statistics Service (NASS) United States. https://www.nass.usda.gov/Publications/Highlights/2019/ 2017Census_Farm_Producers.pdf. Accessed 19 Sept 2020

Nath A, Dutta D, Kumar P, Singh Jp (2015) Review on recent advances in value addition of jaggery based products. J Food Process Technol 6:4-7. https://doi.org/10.4172/2157-7110. 1000440

Nicot JP, Duncan IJ (2012) Common attributes of hydraulically fractured oil and gas production and $\mathrm{CO}_{2}$ geological sequestration. Greenh Gases SciTechnol 2:352-368. https://doi.org/10. $1002 /$ ghg

NITI Aayog (2018) Demand and supply projections towards 2033. Crops, Livestock, Fisheries and agricultural inputs, Working Group Report. https://niti.gov.in/sites/default/files/2019-07/WGReport-issued-for-printing.pdf. Accessed 19 Sept 2020

Pandiselvam R, Sunoj S, Manikantan MR et al (2017) Application and kinetics of ozone in food preservation. Ozone SciEng 39:115-126. https://doi.org/10.1080/01919512.2016.1268947

Patel K, Guenther D, Wiebe K, Seburn RA (2014) Promoting food security and livelihoods for urban poor through the informal sector: a case study of street food vendors in Madurai, Tamil Nadu, India. Food Secur 6:861-878. https://doi.org/10.1007/ s12571-014-0391-z

Pattnayak PK, Misra MK (2004) Energetic and economics of traditional gur preparation: a case study in Ganjam district of Orissa, India. Biomass Bioenerg 26:79-88. https://doi.org/10. 1016/S0961-9534(03)00061-8

Phillips RL (2014) Green revolution: past, present, and future. EncyclAgric Food Syst 3:529-538. https://doi.org/10.1016/ B978-0-444-52512-3.00208-4

Qureshi ME, Dixon J, Wood M (2015) Public policies for improving food and nutrition security at different scales. Food Secur 7:393-403. https://doi.org/10.1007/s12571-015-0443-z

Ramírez CA, Patel M, Blok K (2006) From fluid milk to milk powder: energy use and energy efficiency in the European dairy industry. Energy 31:1984-2004. https://doi.org/10.1016/j.energy.2005.10. 014

Rizou M, Galanakis IM, Aldawoud TMS, Galanakis CM (2020) Safety of foods, food supply chain and environment within the COVID-19. Trends Food SciTechnol 102:293-299. https://doi. org/10.1016/j.tifs.2020.06.008

Rodríguez-Rojas A, ArangoOspina A, Rodríguez-Vélez P, AranaFlorez R (2019) ¿What is the new about food packaging material? A bibliometric review during 1996-2016. Trends Food SciTechnol 85:252-261. https://doi.org/10.1016/j.tifs.2019.01. 016 
Rowan NJ, Galanakis CM (2020) Unlocking challenges and opportunities presented by COVID-19 pandemic for cross-cutting disruption in agri-food and green deal innovations: Quo Vadis? Sci Total Environ 748:141362. https://doi.org/10.1016/j.scito tenv.2020.141362

Sagar VR (2010) Recent advances in drying and dehydration of fruits and vegetables : a review. J Food Sci Technol. 47:15-26 https:// link.springer.com/article/10.1007\%2Fs13197-010-0010-8

Sardeshpande VR, Shendage DJ, Pillai IR (2010) Thermal performance evaluation of a four pan jaggery processing furnace for improvement in energy utilization. Energy 35:4740-4747. https://doi.org/10.1016/j.energy.2010.09.018

Scroll P, For D (2012) The long green revolution. J Peasant Stud 40:37-41. https://doi.org/10.1080/03066150.2012.719224

Solomon S, Pratap G, Swapna RM (2020) Impact of COVID-19 on Indian sugar industry. Sugar Tech 22:547-551. https://doi.org/ 10.1007/s12355-020-00846-7

Thirumdas R, Kothakota A, Annapure U et al (2018) Plasma activated water (PAW): chemistry, physico-chemical properties, applications in food and agriculture. Trends Food SciTechnol 77:21-31. https://doi.org/10.1016/j.tifs.2018.05.007

Thow AM, Kadiyala S, Khandelwal S et al (2016) Toward food policy for the dual burden of malnutrition: an exploratory policy space analysis in India. Food Nutr Bull 37:261-274. https://doi. org $/ 10.1177 / 0379572116653863$

USA F and AO (2020) COVID-19 pandemic-impact on food and agriculture. In: FAO Website

Wu SH, Ho CT, Nah SL, Chau CF (2014) Global hunger: a challenge to agricultural, food, and nutritional sciences. Crit Rev Food SciNutr 54:151-162. https://doi.org/10.1080/10408398.2011. 578764

Xu T, Flapper J (2011) Reduce energy use and greenhouse gas emissions from global dairy processing facilities. Energy Policy 39:234-247. https://doi.org/10.1016/j.enpol.2010.09.037

Publisher's Note Springer Nature remains neutral with regard to jurisdictional claims in published maps and institutional affiliations. 